\title{
Progress toward sodium reduction in the United States
}

\author{
Jessica Levings, ${ }^{1}$ Mary Cogswell, ${ }^{1}$ Christine J. Curtis, ${ }^{2}$ \\ Janelle Gunn, ${ }^{1}$ Andrea Neiman, ${ }^{1}$ and Sonia Y. Angell ${ }^{1}$
}

Suggested citation Levings J, Cogswell M, Curtis CJ, Gunn J, Neiman A, Angell SY. Progress toward sodium reduction in the United States. Rev Panam Salud Publica. 2012;32(4):301-6.

\begin{abstract}
The average adult in the United States of America consumes well above the recommended daily limit of sodium. Average sodium intake is about $3463 \mathrm{mg} /$ day, as compared to the 2010 dietary guidelines for Americans recommendation of $<2300 \mathrm{mg} /$ day. A further reduction to $1500 \mathrm{mg}$ /day is advised for people 51 years or older; African Americans; and people with high blood pressure, diabetes, or chronic kidney disease. In the United States of America, the problem of excess sodium intake is related to the food supply. Most sodium consumed comes from packaged, processed, and restaurant foods and therefore is in the product at the time of purchase. This paper describes sodium reduction policies and programs in the United States at the federal, state, and local levels; efforts to monitor the health impact of sodium reduction; ways to assess consumer knowledge, attitudes, and behavior; and how these activities depend on and inform global efforts to reduce sodium intake. Reducing excess sodium intake is a public health opportunity that can save lives and health care dollars in the United States and globally. Future efforts, including sharing successes achieved and barriers identified in the United States and globally, may quicken and enhance progress.
\end{abstract}

Key words Sodium; world health; United States.

The average adult and child in the United States of America consume well above the recommended daily limit of sodium. Average sodium intake is 3463 $\mathrm{mg}$ /day (1) (Figure 1), as compared to the 2010 dietary guidelines for Americans recommendation of $<2300 \mathrm{mg} /$ day. A further reduction to $1500 \mathrm{mg} /$ day is advised for people 51 years or older; African Americans; and people with high blood pressure, diabetes, or chronic kidney disease (2). These populations

Centers for Disease Control and Prevention, Atlanta, Georgia, United States of America. Send correspondence to: Jessica Levings, isb4@cdc.gov

2 New York City Department of Health and Mental Hygiene, New York, New York, United States of America. account for about half of the U.S. population and the majority of adults (3).

High sodium consumption increases blood pressure, raising hypertension rates and the risk for cardiovascular disease and early death. Globally, hypertension is a leading risk factor for mortality (4). Currently, one-third of U.S. adults have hypertension, which was a primary or contributing cause of approximately 348000 U.S. deaths in 2008 (5). Reducing average daily sodium intake in the population by $400 \mathrm{mg}$ could avert up to 28000 deaths from any cause and could save $\$ 7$ billion in annual health care expenditures in the United States (6). Achieving this reduction is feasible; a $25 \%$ reduction in sodium content of the top 10 food category contributors to sodium intake could result in an $11 \%$ reduction (approximately $360 \mathrm{mg}$ ) in average daily sodium consumption in the United States (7). Despite the strong body of evidence supporting sodium reduction as a means to save lives and health care costs, as is common with policy making, some individuals have questioned the evidence base for public policy related to reduced sodium intake in the population (8).

In the United States, the problem of excess sodium intake is related to the food supply. The majority of sodium consumed comes from packaged, processed, and restaurant foods (9) and therefore is in the product at the time 
FIGURE 1. Mean sodium intake, by age and sex, National Health and Nutrition Examination

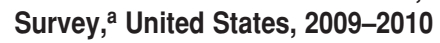

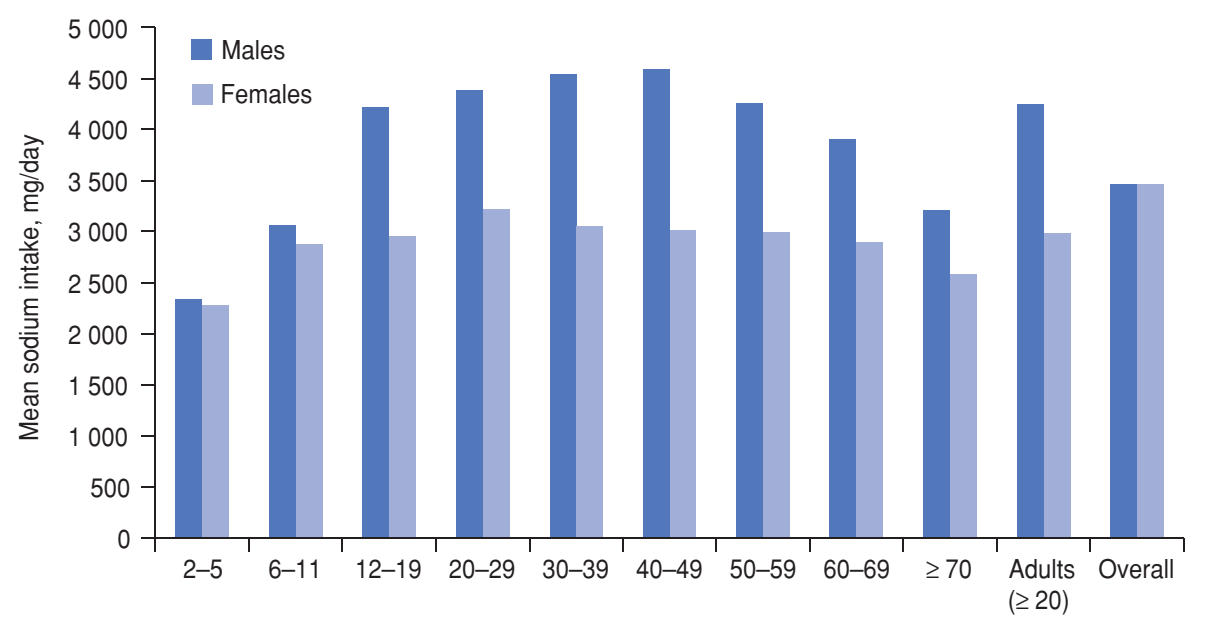

a Reference 1

Age group (years)

of purchase. In 2010, a report by the Institute of Medicine, Strategies to reduce sodium intake in the United States, recommended that the Food and Drug Administration (FDA) set mandatory stepwise targets to lower the sodium content of foods and that the food industry voluntarily reduce the sodium content of foods in the interim (10). To support national initiatives, the Institute of Medicine also recommended more widespread implementation of state and local policies to reduce the amount of sodium in foods served in restaurants and other food service establishments as well as continued and enhanced monitoring of the impact of sodium reduction. The American Heart Association released a Presidential Advisory in 2011 urging a "renewed and intensive focus" on achieving population-wide reduction in sodium intake.

This paper describes sodium reduction policies and programs at the federal, state, and local levels in the United States; efforts to monitor the health impact of sodium reduction; ways to assess consumer knowledge, attitudes, and behavior; and how these activities depend on and inform global efforts to reduce sodium intake.

\section{SODIUM REDUCTION POLICIES AND PROGRAMS IN THE UNITED STATES}

Calls for voluntary reductions of sodium levels in the U.S. food supply have been ongoing for $>40$ years, but success has been limited (10). Sodium intake continues to exceed recommended levels, prompting an increased focus on sodium reduction at all levels of the U.S. government: national, state, and local.

\section{National}

At the federal level, packaged foods are regulated primarily by the FDA (nearly $80 \%$ of the U.S. food supply). The United States Department of Agriculture (USDA) regulates mostly meat and poultry (nearly $20 \%$ of the food supply). While labeling of sodium content on most packaged foods sold to consumers has been mandatory since 1993 (11), labeling of single-ingredient and ground and chopped meat and poultry products did not become mandatory until 2012 (12). Regulations requiring labeling for meat and poultry products injected with a sodium-containing solution are under consideration (13). Additionally, for the first time, federal regulation from the FDA will require that specific types of restaurants and similar retail food establishments with 20 or more locations provide information on the sodium content of menu items (14). In 2011, the USDA and the U.S. Department of Health and Human Services' FDA and Centers for Disease Control and Prevention (CDC) sponsored a public meeting, "Approaches to Reducing Sodium Consumption" (15) to provide an opportunity to comment on current and emerging approaches to reducing sodium intake. Information obtained at this meeting and comments received as part of a public request for comments published in the Federal Register will help inform future actions of federal regulatory agencies.

Sodium reduction is a key component of federal initiatives aiming to improve cardiovascular health, including Million Hearts $^{\mathrm{TM}}$ and Healthy People 2020. Million Hearts ${ }^{\mathrm{TM}}$ aims to prevent 1 million heart attacks and strokes over the next 5 years. A primary goal of the Million Hearts $^{\mathrm{TM}}$ initiative is a reduction in population sodium intake of $20 \%$ by January 1 , 2017, through efforts such as introducing procurement policies to increase access to foods with lower sodium content, increasing public and professional education about the health effects of excess sodium, and collecting and sharing information on sodium consumption (16). Healthy People 2020 provides sciencebased, 10-year national objectives for improving the health of all Americans and aims to motivate improvements in health by encouraging collaborations across communities and sectors, empowering individuals to make informed health decisions, and measuring the impact of prevention activities. One Healthy People 2020 objective for reducing sodium intake is to reduce mean sodium intake by the U.S. population to $2300 \mathrm{mg}$ /day by 2020 . Other examples of federal action are 2012 rules issued by the USDA that reduce the sodium content of school lunches and breakfasts throughout the country (17). The Department of Health and Human Services and the General Services Administration established guidelines for federal vending and concessions that include sodium requirements (18).

Public health agencies and organizations in the United States are also collaborating to promote the importance of sodium reduction through a national effort. The National Salt Reduction Initiative (NSRI) is a broad partnership of $>85$ national and regional health organizations as well as local and state health authorities from across the country. Launched in 2008 and coordinated by the New York City Department of Health and Mental Hygiene (NYC Health Department), the NSRI aims to lower the sodium intake of the U.S. population by $20 \%$ over 5 years by reducing the sodium content of packaged, processed, and restaurant foods by $25 \%$ over that period (19). It is the first national strategy in 
the Americas integrating a framework for voluntary corporate commitments to sodium targets with a multilevel evaluation to capture change in the sodium content of the food supply and in population intake. The model of inviting industry to publicly commit to sodium targets and report on industry achievements is based on the United Kingdom's salt reduction campaign, which published its first set of sodium targets in 2005, to be met by 2008 (20). Through an iterative process of analyzing nutrition and sales data and soliciting feedback from industry, the NSRI has set 2012 and 2014 sodium targets for 62 packaged food and 25 restaurant food categories, along with a maximum sodium level for restaurant items $(21,22)$. To date, 28 food manufacturers, restaurant chains, and supermarkets have publicly committed to meeting NSRI targets. ${ }^{3}$

\section{State}

State-level sodium reduction efforts have also been increasing. For example, the Massachusetts Department of Public Health implemented statewide food standards for food purchased and meals prepared by specific state agencies (23). The Texas Salt Reduction Collaborative was established in 2011 by the Texas Cardiovascular Disease and Stroke Partnership to provide a vehicle for members and the public to receive information on evidence-based programs, practices, and policies (24). The state health department in Indiana is providing procurement training to local business vendors that work with state agencies such as schools, jails, and hospitals on sodium reduction in contracted food items.

\section{Local}

Local jurisdictions are implementing policies and programs to reduce sodium intake. In 2010, CDC launched the Sodium Reduction in Communities Program to help create healthier food environments by reducing sodium intake. Five sites around the country were funded to work with venues such as restaurants, grocery stores, schools, and senior centers to reduce the sodium content of foods consumed and stocked, and

\footnotetext{
3 For more detail on the NSRI, go to nyc.gov/ health/ salt
}

to spearhead changes in procurement policies (25).

Several U.S. cities are developing nutrition standards for foods purchased, distributed, and sold. New York City was the first major U.S. city to introduce nutrition criteria that apply to all foods purchased and served by the city. The standards for foods purchased and served by city agencies were introduced by a mayoral executive order in 2008, followed by standards for beverage and food vending machines in 2009 and 2011, respectively (26). The standards include sodium limits for individual food items and meals while addressing other nutrient requirements, and cover daycare centers, schools, correctional facilities, hospitals, and other venues run or contracted by municipal agencies. The standards affect $>270$ million meals and snacks served each year to New Yorkers and $>4000$ vending machines. Establishing comprehensive nutrition standards supports the goal of providing healthful food to city clients and employees, and uniform standards across city agencies eased vendor compliance. The NYC Health Department is expanding this work to private venues by working with retail food outlets in hospitals and worksites, such as cafeterias.

\section{MONITORING SODIUM REDUCTION}

Monitoring the impact of efforts at the national, state, and local levels will provide data needed to determine success and inform future approaches. Key areas to monitor include the sodium content of packaged, processed, and restaurant foods as well as population sodium intake using dietary and biomarker data.

To monitor the amount of sodium in foods, CDC is working with USDA's Agricultural Research Service and the FDA to track primary contributors to sodium intake (sentinel foods) over time and to determine changes in sodium content. Monitoring sodium and other nutrient contents of these sentinel foods will provide an early indication of how the food supply is changing and how consumers are responding and will focus further investigations and assessments. A variety of additional approaches are being used to monitor the amount of sodium in foods, including developing a packaged food database (to monitor changes within specific food groups); systematically reviewing studies that evaluate the sodium content of restaurant foods to help determine the best system for monitoring; and using existing data to provide reports on the contribution of specific foods to the sodium intake of the population.

Maintaining current databases is challenging because of the frequency of reformulation and the introduction of new products in the marketplace. CDC is collaborating with the USDA in efforts to update the nutrient values of select foods in the USDA National Nutrient Database for Standard Reference. This database forms the basis for other nutrient databases as well as for the development of nutrition label information and nutrition claims by manufacturers (27). Foods in the database, including some restaurant foods, will be updated based on consumption frequency and sodium content, as determined by National Health and Nutrition Examination Survey data. To build capacity for monitoring nutrient content across additional foods and brands and to assess the average and range of sodium content of products, CDC is developing a packaged food database based on sentinel foods that make up the top $80 \%$ of sales volume within USDA food categories, similar to the database developed by the NYC Health Department for the NSRI. The NSRI nutrition databases allow for the analysis of food nutrient content by food category and company over time. The NSRI Packaged Food Database merges sales and nutrition information for 62 packaged food categories, and the NSRI Restaurant Food Database uses market share data for the top 50 restaurant chains (by sales), merged with nutrition data, for 25 restaurant food categories (28). Data on average sodium content by category at baseline in 2009 are available online. ${ }^{4}$ The databases are being updated in 2012 to assess changes in the sodium content of U.S. foods.

To better understand population intake of sodium and related nutrients, the federal government collects and analyzes a variety of data. One example is a recent study designed to update understanding of the typical sources of dietary sodium intake (including sodium from

\footnotetext{
Available from: http://www.nyc.gov/html/doh/ downloads/pdf/cardio/cardio-salt-nsri-packaged. pdf
} 
processed and restaurant foods, sodium inherent in foods, and salt added at the table and during cooking).

To monitor sodium intake, the CDC, National Institutes of Health, USDA, and FDA continue to collect and analyze 24hour recall data on dietary sodium and related nutrients (e.g., potassium and iodine $^{5}$ ) from the National Health and $\mathrm{Nu}$ trition Examination Survey. Biomarker data may better capture all sources of sodium intake (e.g., foods, salt added at the table, medications) and can be more accurate than self-reports (29). Ongoing activities include assessment of historic and spot urine specimens and previously collected data to inform trends in sodium and potassium intake. New data collection and analyses include spot urine specimens for estimating population sodium intake. Potential limitations for using spot urine specimens to estimate population sodium intake include large diurnal variations in sodium excretion during the day, an increase in urine dilution overnight with aging, and the fact that specimens may not reflect the diet of the individual unless the diet is very stable. CDC is assessing the potential use of random (spot) urine collection to estimate 24-hour sodium excretion at the population level.

At the local level, the NYC Health Department assessed sodium intake based on a 24-hour urine collection from $>1600$ adult New Yorkers, weighted to represent the New York City population. Called the "Heart Follow-Up Study," it was the first representative, populationbased study in the United States to assess sodium intake by this methodology. Key variables collected include an objective measurement of sodium intake, seated blood pressure, measured height and weight, and self-reported health and diet information, all of which are vital to understanding changes in sodium intake related to the NSRI and local efforts in

\footnotetext{
5 While iodine deficiency disorders are less prevalent in the United States, they are a serious global public health challenge and a leading cause of preventable childhood brain damage. To prevent iodine deficiency disorders, universal salt iodization programs are supported by most countries, and voluntary use of fortified salt in prepackaged and processed foods is increasingly being encouraged. It is plausible that the opportunity to reduce sodium intake while increasing iodine fortification can be achieved if supported by the top food companies to positively affect global public health. In the United States, salt used in food processing is not iodized.
}

New York City (30). A full report of the findings is pending, and follow-up assessment of population sodium intake in New York City is planned.

\section{ASSESSING CONSUMER KNOWLEDGE, ATTITUDES, AND BEHAVIOR RELATED TO SODIUM REDUCTION}

Consumer awareness can drive action aimed at reducing sodium intake. CDC monitors knowledge, attitudes, and behaviors pertaining to individual sodium intake (31-35). Additional questions to assess consumer behavior relating to sodium intake will be incorporated in the Behavioral Risk Factor Surveillance System to be conducted in 2013. CDC also monitors health care costs and health outcomes related to reduced sodium intake. The Data Trends and Maps website provides annual national- and state-level data on risk factors for cardiovascular disease. ${ }^{6}$ In addition, CDC is working with academic partners to evaluate the cost-effectiveness of interventions designed to reduce sodium intake, model the impact of reduced sodium intake on mortality, and examine associations of usual sodium intake with all-cause and cardiovascular disease deaths to further assess the health and economic impact of reduced sodium intake (36).

Efforts to reduce sodium intake in the United States have been increasing yet are still fairly new; thus, evaluation efforts assessing the impact of these programs on population health remain under development.

\section{GLOBAL RELEVANCE OF EFFORTS TO REDUCE SODIUM INTAKE IN THE UNITED STATES}

As described, efforts to reduce population sodium intake in the United States are increasingly implemented at the federal, state, and local levels, with a primary focus on decreasing the amount of sodium in packaged, processed, and restaurant foods, the main sources of sodium in the U.S. diet. The U.S. focus may be increasingly relevant to many low- and middle-income countries that have experienced a nutrition transition (37), marked by a shift from traditional

\footnotetext{
6 Available from: http://apps.nccd.cdc.gov/NCVDSS_ DTM/
}

diets and active lifestyles to ones increasingly characterized by consumption of packaged, processed, and restaurant foods accompanied by physical inactivity. ${ }^{7}$ For example, over the past 20 years increased consumption of sugary beverages, processed meats, and breads and reduced consumption of rice, beans, and other unprocessed ingredients have been reported in Brazil (38). This transition has been facilitated partly by global migration into urban settings, with Latin America experiencing one of the most rapid demographic shifts from a largely rural to a mostly urban society. Another major contributor to urbanization has been globalization, with countries becoming interconnected by economic growth and development (39). As a result of both of these changes, many food and beverage companies and food retailers in the United States have extended their reach into world markets, so that global and U.S. processed food markets are increasingly similar and connected.

With this convergence comes opportunity. Lessons learned in the United States on reducing sodium in the food supply may have increasing relevance in other regions. This includes models at the national and local levels for working with private industry, changing government procurement practices, and instituting nutrition labeling. Conversely, because major corporations producing in and for the U.S. marketplace also manufacture for other regions, actions undertaken to reduce the sodium content of packaged and processed foods in countries within this regional marketplace but outside the United States are likely relevant to the United States. For example, bread is the largest contributor to sodium intake in the United States. Mexican-owned and -headquartered Grupo Bimbo, the world's leading producer of bakery brands and the fourth largest global food corporation, owns common U.S. household brand names such as Sara Lee and Entenmann's. Technology used by Grupo Bimbo to reduce the amount of sodium in its Mexican products could serve as a reference for similar reductions

\footnotetext{
Pan American Health Organization. The WHO global strategy on diet, physical activity, and health, implementation plan for Latin America and the Caribbean 2006-2007 [unpublished document]. Washington, D.C.: PAHO; 2006. Available from: http:// apjen.nhri.org.tw/server/APJCN/Volume10/vol 10supp/Popkin.pdf Accessed 5 November 2012.
} 
in the United States. Further, innovations in the United States could provide information for reformulating Mexican products. Lessons learned from national surveillance of packaged, processed, and restaurant foods may provide further insight and opportunities for the United States and other countries. Packaged and restaurant food databases in other countries can be used to identify successful sodium reductions in products also sold in the United States, potentially inform- ing innovations in the United States and beyond. Successful reduction of sodium intake in one country creates the potential for success in all countries.

\section{Conclusion}

Reducing excess sodium intake is a public health opportunity that can save lives and health care dollars in the United States and globally. Innovative sodium reduction initiatives, and corre- sponding improvements in monitoring and surveillance, are under way at all levels of government across the United States. Future efforts, including sharing of successes achieved and barriers identified in the United States and globally, may quicken and enhance progress.

Disclaimer. The findings and conclusions in this report are those of the authors and do not necessarily represent the official position of the CDC.

\section{REFERENCES}

1. U.S. Department of Agriculture. What we eat in America, 2009-2010. National Health and Nutrition Examination Survey. Washington, D.C.: USDA; 2012. Available from: http://www.ars.usda.gov/Services/docs. htm?docid=18349 Accessed 1 October 2012.

2. U.S. Department of Agriculture and U.S. Department of Health and Human Services. Dietary guidelines for Americans 2010. 7th ed. Washington, D.C.: U.S. Government Printing Office; 2010.

3. Centers for Disease Control and Prevention. Application of lower sodium intake recommendations to adults-United States, 1999-2006. MMWR Morb Mortal Wkly Rep. 2009;58(11);281-3.

4. Asaria P, Chisholm D, Mathers C, Ezzati M, Beaglehole R. Chronic disease prevention: health effects and financial costs of strategies to reduce salt intake and control tobacco use. Lancet 2007;370(9604):2044-53.

5. Roger VL, Go AS, Lloyd-Jones DM, Benjamin EJ, Berry JD, Borden WB, et al. Heart disease and stroke statistics-2012 update: a report from the American Heart Association. Circulation. 2012;125:e2-220.

6. Bibbins-Domingo K, Chertow GM, Coxson PG, Moran A, Lightwood JM, Pletcher MJ, et al. Projected effect of dietary salt reductions on future cardiovascular disease. $\mathrm{N}$ Engl J Med. 2010;362:590-9.

7. Centers for Disease Control and Prevention. Vital signs: food categories contributing the most to sodium consumption-United States, 2007-2008. MMWR Morb Mortal Wkly Rep. 2012;61(5):1-7.

8. Appel LJ, Angell SY, Cobb LK, Limper HM, Nelson DE, Samet JM, et al. Population-wide sodium reduction: the bumpy road from evidence to policy. Ann Epidemiol. 2012;22(6): 417-25.

9. Mattes RD, Donnelly D. Relative contributions of dietary sodium sources. J Am Coll Nutr. 1991;10:383-93.

10. Institute of Medicine. Strategies to reduce sodium intake in the United States. Washington, D.C.: National Academies Press; 2010. Available from: http://www.iom.edu/ reports / 2010/strategies-to-reduce-sodiumintake-in-the-united-states.aspx Accessed 3 April 2012.

11. Food labeling: mandatory status of nutrition labeling and nutrient content revision, format for nutrition label. Final rule. Fed Regist. 1993; 58:2079-205.

12. Nutrition labeling of single-ingredient products and ground or chopped meat and poultry products. Final rule. Fed Regist. 2010;75: 82147-67.

13. Common or usual name for raw meat and poultry products containing added solutions. Proposed rule. Fed Regist. 2011;76:69146-7.

14. Food labeling; nutrition labeling of standard menu items in restaurants and similar retail food establishments. Proposed rule. 2011;76:19191-236. Available from: http:// www.gpo.gov/fdsys/pkg/FR-2011-04-06/ html/2011-7940.htm Accessed 18 April 2012.

15. Approaches to reducing sodium consumption; public meeting. Notice of public meeting; request for comments. Fed Regist. 2011; 76:63305-8. Available from: http:/ / www.gpo. gov/fdsys/pkg/FR-2011-10-12/html/201126371.htm Accessed 18 April 2012.

16. Preventing 1 million heart attacks and strokes by 2017: the Million Hearts Initiative. Atlanta: Centers for Disease Control and Prevention Public Health Grand Rounds; 2012. Available from: http://www.cdc.gov/about/ grand-rounds/archives/2012/february2012. htm\#presentation Accessed 18 April 2012.

17. Nutrition standards in the national school lunch and school breakfast programs. Final rule. Fed Regist. 2012;77:4087-167.

18. Department of Health and Human Services and General Services Administration. Health and sustainability guidelines for federal concessions and vending operations. Washington, D.C.: Department of Health and Human Services; 2011. Available from: http:/ / www.gsa. gov/graphics/pbs/Guidelines_for_Federal Concessions_and_Vending_Operations.pdf Accessed 18 April 2012.

19. Angell SY, Farley TA. Can we finally make progress on sodium intake? Am J Public Health. 2012;102(9):1625-7.

20. Food Standards Agency. UK salt reduction initiatives. London:FoodStandards Agency;2009. Available from: http://www.food.gov.uk/ multimedia/pdfs/saltreductioninitiatives. pdf Accessed 18 April 2012.

21. National Salt Reduction Initiative. Packaged food categories and targets. New York: NSRI; 2012. Available from: http://www.nyc.gov/ $\mathrm{html} /$ doh/downloads/pdf/cardio/cardiosalt-nsri-packaged.pdf Accessed 18 April 2012.
22. National Salt Reduction Initiative. Restaurant categories and targets. New York: NSRI; 2012. Available from: http://www.nyc.gov/html/ doh/downloads/pdf/cardio/cardio-saltnsri-restaurant.pdf Accessed 18 April 2012.

23. Massachusetts State Agency Food Standards. Requirements and recommendations. Boston: Massachusetts Department of Public Health; 2012. Available from: http://www. mass.gov/eohhs/docs/dph/com-health/ nutrition-phys-activity/eo509-state-agencyfood-standards.pdf Accessed 18 April 2012.

24. Texas Department of State Health Services. Texas Salt Reduction Collaborative. Austin: Texas Department of State Health Services; 2011. Available from: https:/ / www.dshs.state. tx.us/wellness/Texas-Salt-Reduction-Collab orative.doc Accessed 18 April 2012.

25. Centers for Disease Control and Prevention. Sodium reduction in communities. Atlanta: CDC; 2012. Available from: http://www.cdc. gov/dhdsp/programs/sodium_reduction. htm Accessed 18 April 2012.

26. New York City Department of Health and Mental Hygiene. New York City food standards. New York: New York City Department of Health and Mental Hygiene; 2012. Available from: http://www.nyc.gov/html/doh/ $\mathrm{html} /$ cardio/cardio-vend-nutrition-standard. shtml Accessed 18 April 2012.

27. U.S. Department of Agriculture, Agricultural Research Service. USDA national nutrient database for standard reference, release 24 . Washington, D.C.: USDA; 2011. Available from: http://www.ars.usda.gov/ba/bhnrc/ ndl Accessed 18 April 2012.

28. Institute of Medicine. Strategies to reduce sodium intake in the United States. Appendix G. Washington, D.C.: National Academies Press; 2010. Available from: http://www. iom.edu/reports/2010/strategies-to-reducesodium-intake-in-the-united-states.aspx Accessed April 3, 2012.

29. Willett W. Nutritional epidemiology. 2nd ed. Monographs in epidemiology and biostatistics. Vol. 30. New York: Oxford University Press; 1998. Pp. 209-10.

30. New York City Department of Health and Mental Hygiene. Health Department announces new company commitments to National Salt Reduction Initiative; sodium study confirms that New Yorkers eat too much salt. Press release. New York: New York City 
Department of Health and Mental Hygiene; 2011. Available from: http://home2.nyc.gov/ $\mathrm{html} / \mathrm{doh} / \mathrm{html} / \mathrm{pr} 2011 / \mathrm{pr} 005-11$.shtml Accessed 18 April 2012.

31. Fang J, Cogswell M, Keenan NL, Merritt RK. Primary health care providers' attitudes and counseling behaviors related to dietary sodium reduction. Arch Intern Med. 2012;172(1):76-8.

32. Centers for Disease Control and Prevention. Usual sodium intakes compared with current dietary guidelines-United States, 2005-2008. MMWR Morb Mortal Wkly Rep. 2011;60(41): 1413-7.

33. Ayala C, Tong X, Valderrama A, Ivy A, Keenan N. Actions taken to reduce sodium intake among adults with self-reported hypertension: HealthStyles survey, 2005 and 2008. J Clin Hypertens (Greenwich). 2010;12:793-9.

34. Valderrama AL, Tong X, Ayala C, Keenan NL. Prevalence of self-reported hypertension, advice received from health care professionals, and actions taken to reduce blood pressure among US adults-HealthStyles, 2008. J Clin Hypertens (Greenwich). 2010;12:784-92.

35. Ayala C, Gillespie C, Cogswell M, Keenan NL, Merritt R. Sodium consumption among hypertensive adults advised to reduce their intake-National Health and Nutrition Examination Survey, 1999-2004. J Clin Hypertens (Greenwich). 2012;14:447-54.

36. Yang Q, Liu T, Kuklina EV, Flanders WD, Hong Y, Gillespie C, et al. Sodium and potassium intake and mortality among US adults: prospective data from the Third National Health and Nutrition Examination Survey. Arch Intern Med. 2011;171(13):1183-91.

37. Popkin B. Nutrition in transition: the changing global nutrition challenge. Asia Pacific J Clin Nutr. 2001;10(Suppl):S13-8. Available from: http://apjcn.nhri.org.tw/server/ APJCN/Volume10/vol10supp/Popkin.pdf Accessed 5 November 2012.
38. Monteiro CA, Levy RB, Claro RM, Ribeiro de Castro IR, Cannon G. Increasing consumption of ultra-processed foods and likely impact on human health: evidence from Brazil. Public Health Nutr. 2011;14(1):5-13.

39. Friedman TL. The world is flat: a brief history of the twenty-first century. New York: Farrar, Straus, Reese, and Giroux; 2005

Manuscript received on 31 May 2012. Final version accepted for publication on 29 October 2012.

RESUMEN El adulto medio de los Estados Unidos consume una cantidad de sodio muy por encima del límite diario recomendado. La ingesta promedio de sodio es aproximadamente de $3463 \mathrm{mg} /$ día, en contraste con la recomendación de las Directrices alimentarias del

Progresos hacia la reducción del sodio en los Estados Unidos 2010 para estadounidenses que es de menos de $2300 \mathrm{mg} /$ día. A las personas de 51 años o mayores, los afroestadounidenses, los hipertensos, los diabéticos o los que padecen una nefropatía crónica, se les recomienda una reducción adicional hasta $1500 \mathrm{mg} /$ día. En los Estados Unidos, el problema de la ingesta excesiva de sodio está relacionado con el suministro en los alimentos. La mayor parte del sodio consumido proviene de los alimentos envasados, procesados y que se sirven en restaurantes y, por consiguiente, ya está en el producto en el momento de la compra. Este artículo describe las políticas y los programas de reducción del sodio en los Estados Unidos a escalas federal, estatal y local; las iniciativas para vigilar la repercusión de la reducción del sodio en la salud; los procedimientos para evaluar los conocimientos, las actitudes y el comportamiento de los consumidores; y cómo estas actividades dependen de las iniciativas a escala mundial para reducir la ingesta de sodio y les proporcionan información. La reducción de la ingesta excesiva de sodio constituye una oportunidad de salud pública que puede salvar vidas y ahorrar dinero destinado a la atención de salud en Estados Unidos y a escala mundial. Las iniciativas futuras, entre ellas el intercambio de información sobre los éxitos logrados y los obstáculos encontrados en los Estados Unidos y a escala mundial, pueden acelerar y estimular el progreso.

Palabras clave Sodio; salud mundial; Estados Unidos. 